\title{
Family agriculture and the sustainable development issue: possible approaches from the African oil palm sector. The example of Ivory Coast and Cameroon
}

\author{
Emmanuelle CHEYNS ${ }^{1}$ \\ Sylvain RAFFLEGEAU ${ }^{2}$ \\ ${ }^{1}$ CIRAD, UR Normes et régulation des marchés, \\ Montpellier, France \\ ${ }^{2}$ CIRAD, UR Performance des systèmes de \\ culture de plantes pérennes / IRAD, La Dibamba, \\ Cameroon
}

\begin{abstract}
Based on the results of studies conducted in Ivory Coast and Cameroon, the article proposes an analysis of the family agriculture situation in the oil palm commodity chain, repositioning it within a context of sustainable development issues. At a time when production standards are back on the agenda with so-called "voluntary commitment" processes, through "private standards" to enable sustainable agriculture, the authors examines the outcome of the previous phases of family agriculture standardization by Estates and State-owned companies between 1960 and 1990, followed by privatization of the sector. The article shows that family agriculture possesses its own rationality which needs to be taken into consideration, if the stakes, over and above guaranteeing "sustainable oil", are indeed those of the impact that the palm oil sector has on "sustainable development". Starting from that point, the question is no longer: how can family agriculture take on board technical standards designed for other production models, but how can family agriculture take part in the compromises negotiated in the commodity chain in such a way that its logics and operating methods are considered when drawing up production choices? An analysis of surveys on oil palm-based cropping and farming systems makes it possible a) to specify the logics underlying production practices and to show their specificity, b) and reiterate the minimum conditions required in order for this agriculture, which is the major agriculture in some countries, to achieve the socio-economic reproduction level of the household and not only of the plot: access to capital and information, minimum land areas and prices, representation on negotiating bodies.
\end{abstract}

Key words: family agriculture, oil palm, sustainable development, Ivory Coast, Cameroon

on the production potential of countries in the Gulf of Guinea. In all, around 350,000 ha were planted with selected planting material between 1960 and 1980, of which 220,000 ha were estates [1]. The model adopted arose from a compromise between rural development requirements (road building, diversification of rural agricultural incomes, etc.), and profitability and efficiency (increasing oil yields), resulting in a "contract" whereby outgrowers were committed to respecting recommended farm management standards that maximized yield, and to supplying all their production to the oil mill. Public development companies guaranteed farmers their inputs and planting material (on a credit basis), technical support, FFB collection and track upkeep. The production delivered to the oil mill served to guarantee its supplies and enable credit recovery. The creation of development funds also made it possible to ensure a funding and credit system internal to the commodity chain. In Ivory Coast and Cameroon such funds led to the creation of 77,000 ha of oil palm smallhold- ings in Ivory Coast (between 1963 and 1990) and 12,000 ha in Cameroon (between 1977 and 1991) with selected planting material [2, 3]. While this system enabled the adoption of a new crop, by providing information and capital, particularly on family farms, it was also a source of tension between estate production standards and family production logic, the outcome of which can be summed up today and lessons can be learnt, insofar as the question of standards is back on the agenda in debates on sustainable development.

At the end of the 1990s, liberalization policies spurred on by the international agencies led to the privatization of these State companies. The assets of State-run agroindustrial companies (estates and oil mills) were bought by private enterprises. As in many other agricultural sectors, the abolition of State monopolies led to the emergence of oligopolistic market structures. Privatization also generated a set of changes that rendered the system insecure: emergence of new stakeholders, poor coordination, decentralization of decision-making 
centres and the disappearance of the creditbased seed and fertilizer funding system [4]. The drop in international market prices since 1999, which impacted on the FFB purchase price in Ivory Coast, added to this context of uncertainty. Changes in production methods and the development of oil palm smallholdings increased in pace. The risk limitation option of diversification and taking advantage of local demand to sell FFB on the domestic market, which was barely affected by the uncertainties of the international market and the constraints of an oligopolistic market, fitted in with this logic. The insecurity of the system strengthened a security stance among family farmers, which further widened the gap between a cash crop monoculture (industries) and local trading by family farms, and raised the question of how the different industrial, non-industrial and family production and processing systems interrelated [5].

Lastly, more recently, new international concerns for "sustainable" oil palm growing, expressed through new "multistakeholder" consultation processes, notably the Roundtable on Sustainable Palm Oil (RSPO), have been raising new questions about the future of family agriculture. The Roundtable, which is geared towards defining a list of sustainable production "criteria", has reintroduced the question of production standards, albeit in another perspective. Yet the process barely enlists family farmers who, being virtually absent from the international consultation bodies, could be affected by the introduction of standards, even voluntary, that will govern access to certain markets, European for the moment.

In this context of major changes in the national and international governance of agricultural commodity chains, but also of increasing calls and demands for production sustainability, the purpose of this article is to examine the current situation in which oil palm-based family farms find themselves, focusing on two countries, Cameroon and Ivory Coast.

Family agriculture ${ }^{3}$ is often described in its "social" dimension (it enables the "social fabric" to be maintained in rural zones, etc.). By taking this approach it can be established that

\footnotetext{
${ }^{3}$ Family agriculture includes producers often referred to as "smallholders". A "family farm" is a production unit linked to a family structure, with a strong reliance on family labour. We use the term "smallholder" here to mean the same thing. For more information, refer to R. Sanz Cortés [6]. "Non-estate plantations" or "outgrower plantations" in Cameroon and Ivory Coast very largely consist of this category of family farmers (but they also include other forms in their definition, such as "farming enterprises").
}

this agriculture organizes its production activity within a social framework and, consequently, that its efficiency cannot be compared to the efficiency standards of a non-family industry, for example, but we shall nonetheless provide a few reminders of some major differences here.

However, this vision bears the risk of suggesting that family agriculture, whilst social, is not technical. Yet results taken from different studies show that the technical component lies at the heart of this farming system, which largely contributes to world crude palm oil production, and accounts for the totality of world non-industrial palm oil production. This system, which is based on concepts other than the profitability of estates, is connected to the markets, capable of adapting fairly rapidly, and meets a certain rationality.

This dual social and technical dimension needs to be reconsidered, be it with regard to research or with regard to the definition of "sustainable" oil palm cultivation.

\section{Material and methods}

The results described here are based on statistical surveys conducted among agricultural producers and on in-depth interviews with operators in these oil palm commodity chains in Cameroon (since 1999) and in Ivory Coast ${ }^{4}$ (from 1999 to 2002), and on participation in national roundtables in Ivory Coast.

We shall be looking at aspects of the following surveys (described in greater detail elsewhere, see bibliography):

a) Survey in Ivory Coast, in the lagoon region. The survey involved 150 growers in the Dabou and Anguédédou production zones, in December 2000 and January 2001. Twelve villages were selected in a rational manner and the growers were proportionally drawn at random. The survey covered 401 oil palm plots, representing around 1000 ha. Half of the growers interviewed had under 4 ha of oil palms, and $90 \%$ had under 10 ha [7].

\footnotetext{
$\overline{{ }^{4} \text { The work }}$ undertaken in Ivory Coast was part of a Research-Development programme implemented with LESOR (the rural economics and sociology laboratory at the University of Bouaké).
}

b) Survey in Ivory Coast, in the Aboisso region. The survey involved 117 growers in 3 villages (Koffikro, Baffia, Assouba), in July 2002. The sample was not representative of an overall population, as it was established according to a quota system in order to compare 3 types of growers: (i) cocoa growers who had adopted oil palm growing, (ii) cocoa growers who had not adopted oil palm growing, (iii) former cocoa farmers who had switched to oil palm growing. The survey covered an area of 1,963 ha, all crops combined (including uncultivated areas) [8].

c) Survey in Ivory Coast, at the La Mé research station. The survey involved a sample of 80 smallholders, as they arrived at the La Mé station to buy planting material, in 1999. The sample was not representative of the population of oil palm growers, as the survey only covered buyers of selected planting material, who thus had capital for such a purchase. However, it made it possible to characterize the profile of growers coming to procure selected planting material [9].

d) Survey in Ivory Coast, in 4 zones (Dabou, Aboisso, Divo, Soubré). The survey involved 100 growers, in September 2000, in 13 villages chosen in these 4 regions [9].

e) Survey in Cameroon, in 4 zones: (i) Southwest ( 9 farms), in the PAMOL zone (included in the FONADER project), (ii) Littoral province (64 farms), in the agroindustrial zone (public development companies and private companies, intervention zone favoured by the FONADER project), (iii) South (6 farms), a zone outside the FONADER project, and (iv) southwestern part of Centre province (21 farms), which is a zone without oil mills and nucleus estates. The survey was conducted in 2000 and involved 100 farms. On each farm, 2 plots were inspected where possible, one with bearing palms, the other with juvenile palms (169 plots observed). The sample was non-representative (non-random poll), but aimed at a comparative characterization by type. It comprised 57 farmers, 32 managers or employees, 11 members of the local "elite". Thirty-eight growers had under 5 ha, 24 had between 5 and 10 ha, 38 had more than 10 ha (10 of whom had more than $50 \mathrm{ha}$ ) [10].

Table 1. Selected oil palm areas in 2000 in 4 African producing countries.

\begin{tabular}{|lccc|}
\hline & Estate areas & Smallholder areas & Share of smallholder areas in total areas \\
\hline Ivory Coast & 87828 & 140621 & $61 \%$ \\
Cameroon & 51830 & 43000 & $45 \%$ \\
Nigeria & 25174 & 48867 & $65 \%$ \\
DRC & 56376 & 867 & $1.5 \%$ \\
\hline
\end{tabular}

Source: Jannot, 2003 


\section{Contribution of family agriculture}

\section{A major contribution to palm oil production}

Taking areas set up with selected planting material ${ }^{5}$, the "smallholder" areas in Ivory Coast and Cameroon amount to 45 and $61 \%$ of the total areas planted to oil palm respectively (table 1). This sector therefore makes an not insubstantial contribution to palm oil production $^{6}$.

In Ivory Coast, smallholdings supply $60 \%$ of national FFB production $(1,200,000 \mathrm{t}$ FFB in 2001) [11]

In both Ivory Coast and Cameroon, the enthusiasm of smallholders for oil palm has been particularly notable since the 1990s, including after the commodity channel's internal credit-based funding system was abolished. At the end of the second Ivorian oil palm plan (1990), after three decades of funded development, albeit with planned and restricted access, smallholdings accounted for $54 \%$ of the areas planted. The attribution of seedlings was controlled and decided by the State company. In 1995, access to seeds was opened up to any grower who wanted; a planting boom was thus triggered: the equivalent of 70,000 ha of selected oil palms was sold to growers (in so-called "smallholder" areas) between 1995 and 2000 , i.e. an annual average of 11,800 ha of smallholder areas planted, exceeding the annual average seen during the first two "oil palm plans" $[3,12]$.

The same process of strong growth in smallholder areas was also seen in Cameroon. Between 1996 and 2001, estate extensions and replantings amounted to a third of smallholder extensions and creations (estimation based on seed sales). Smallholders thus succeeded in setting up oil palm plantings (table 2), bringing into play their own investment capacity, thereby giving rise to a significant increases in area. In addition, national production was rising through an increase in non-industrial oil production resulting from the vitality of the smallholder sector, combined with the development of small-scale oil processing, whereas the agroindustries with their ageing planta-

\footnotetext{
$\overline{5}$ To which need to be added the smallholder areas planted with unselected seeds, which have not been quantified on a national scale.

${ }^{6}$ In order of decreasing importance, the main four palm oil producing countries in Africa are Nigeria (910 000 t), Ivory Coast (276,000 t), DRC (191,000 t) and Cameroon $(160,000$ t). Africa produced around 2 million tonnes of crude palm oil in 2004. FAOSTAT data, 2004. Latest update, February 2004.
}

Table 2. Areas planted (ha) Cameroon.

\begin{tabular}{|lcccccccc|}
\hline Year & $\mathbf{1 9 9 6}$ & $\mathbf{1 9 9 7}$ & $\mathbf{1 9 9 8}$ & $\mathbf{1 9 9 9}$ & $\mathbf{2 0 0 0}$ & $\mathbf{2 0 0 1}$ & Total & Mean \\
\hline Estates $^{\mathrm{a}}$ & 2594 & 1568 & 1101 & 1846 & 690 & 1468 & 9267 & 1544 \\
Smallholdings $^{\mathrm{b}}$ & 2939 & 2325 & 4759 & 6077 & 6576 & 6186 & 28862 & 4810 \\
\hline
\end{tabular}

Source: Bakoumé et al., 2002

a Source: agroindustries.

b Source: estimated from direct sales of germinated seeds (ratio of 200 germinated seeds/ha of plantings), to which is added an estimation of the seedlings produced by estates and sold to farmers (number of germinated seeds/200 - number of ha planted by agroindustries). tions were beginning to replant and were maintaining their level of CPO production. In future, with forest and land occupation constraints, and also due to the rural development demands promoted by politicians (see speech by the Indonesian Minister of Agriculture at the second RSPO meeting), family agriculture is set to make an increasing contribution to oil production.

\section{Connections with the markets}

In zones where "nucleus estates" were established, grower contracts specified FFB delivery to the State company. Privatization/ liberalization put the market back at the centre of regulations and established that production assets and trading rights were open. Although rarely encouraged in the past, non-industrial palm oil processing, as a second outlet for smallholder FFB, developed more widely (with little outside help), especially in regions close to urban centres (figure 1). In cases where large oil mills substantially depended on smallholder supplies, their need to plan their supplies came up against competition.
One peculiarity in Africa is that non-industrial palm oil has current and potentially substantial outlets on the local market: red oil consumption by households and supplies to local soap factories (small-scale and industrial). In Ivory Coast, Cameroon and Ghana, certain investigations indicate that urban households consume red palm oil in relatively large quantities, and that non-industrial red oil is highly appreciated for traditional dishes [13-15] (figure 2). In some cases, non-industrial red oil produced from the fruits of local (or "natural") oil palms is preferred to that produced from fruits of selected oil palms; in these cases, the oil from so-called "natural" palms is judged to be more fluid, redder and better [13].

Establishing FFB purchase prices is a delicate matter. In Ivory Coast, private primary processing companies hold a position of virtually unique buyers (monopsony) for bunches in a given production zone, due to structural inertia, except in zones near Abidjan, where nonindustrial and semi-industrial processing has developed strongly. FFB purchase prices are therefore not determined by a competitive

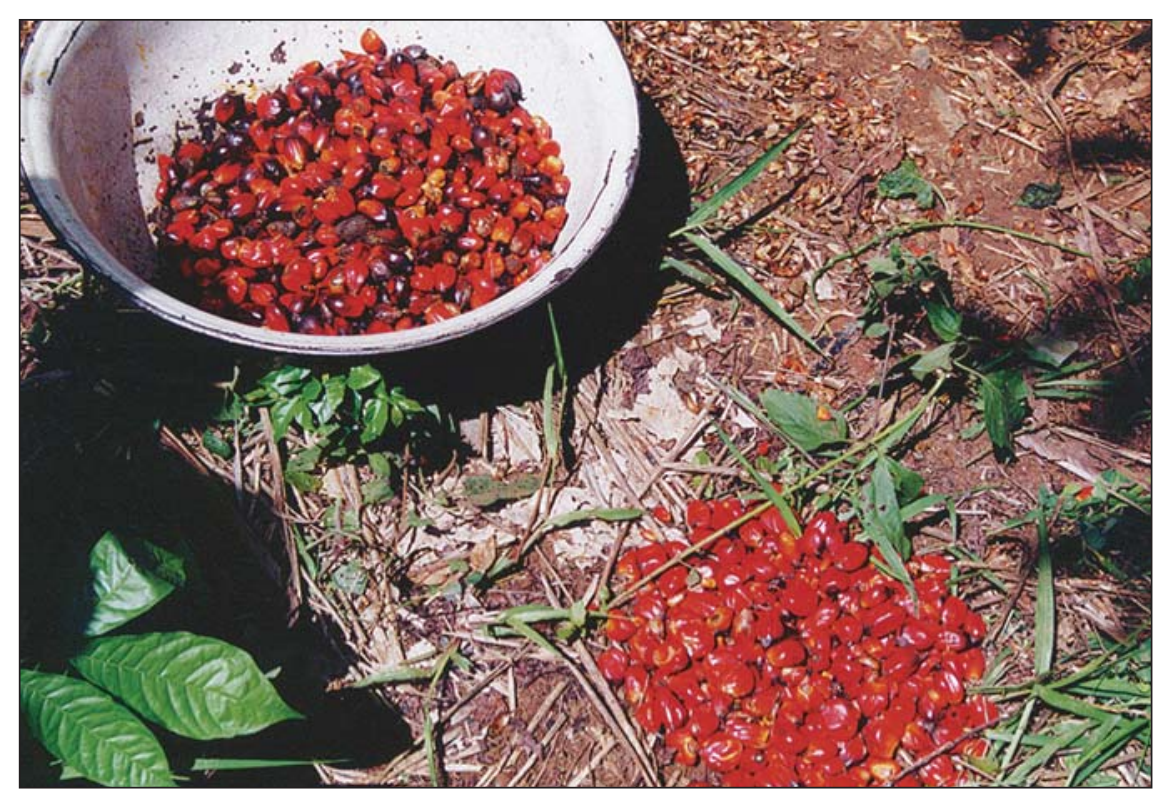

Figure 1. Oil palm fruits. Photo taken on a small-holding 


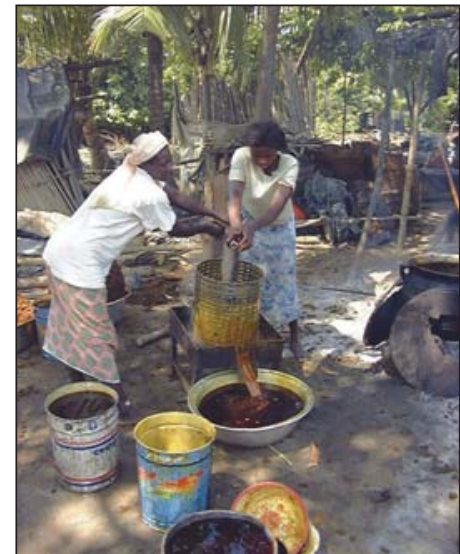

Figure 2. Small-scale processing in Cameroon with a hand press. Photo : Sylvain Rafflegean

market situation. Partly because of this particular market structure, stakeholders in the Ivorian commodity chain base themselves on a "pricing mechanism" a calculation formula for establishing the FFB purchase price, which is a unique price (national). Changes in the parameters of the formula over time require the participation of growers, of the State and of private companies to adjust the open-ended parameters. Producer cooperatives represent smallholders in negotiations. In 1999, after a sharp decline in international market prices (figure 3), these cooperatives criticised the existing pricing mechanism (inherited from the old structure prior to privatization), leading to its revision in 2002, within a framework of new "consultation bodies".

The situation is different in Cameroon, due to customs protection ${ }^{7}$, which shelters the national price from international fluctuations. FFB purchase prices are therefore higher in Cameroon (compared to Ivory Coast) ${ }^{8}$, but agroindustries decide unilaterally what price they pay to growers for FFB. In addition, FFB processing outside oil mills is also much more developed in this country. Over the 2002 season, around $50,000 \mathrm{t}$ of FFB were processed by industrial oil mills and 94,000t via the nonindustrial sector. The turnover generated through selling outgrower FFB to oil mills amounted to around 2 million CFA F; the turnover generated by non-industrial oil sales was

\footnotetext{
7 There is $30 \%$ customs protection for imports intended for resale and $10 \%$ for imports of raw materials intended for secondary processing industries.

${ }^{8}$ Between 1999 and 2002 in Cameroon, the agroindustries bought $F F B$ for between 32 and 40 CFA F/kg at the farmgate, i.e. around ten CFA francs more than in Ivory Coast. (In some zones, these prices fell in 2002. Since April 2005 they have varied between 32 and 35 CFA F.).
}

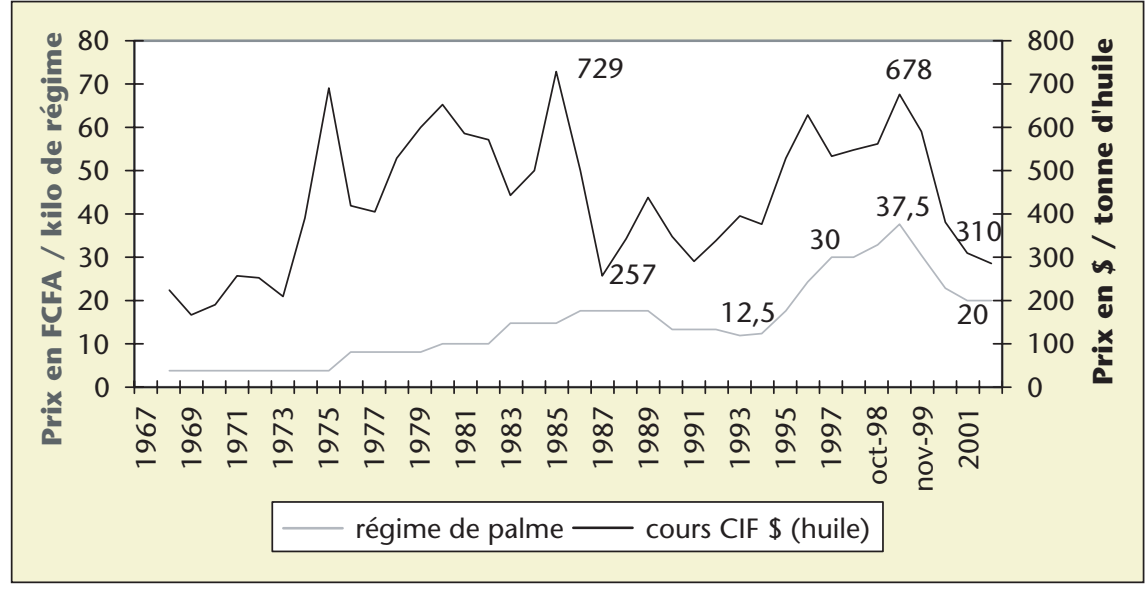

Figure 3. International price trends for crude palm oil and FFB prices in Ivory Coast - 1967-2001.
4.7 million CFA F ${ }^{9}[16]$. In Ivory Coast nonindustrial processing, which was officially banned prior to privatization, still remains a minority activity.

The opportunities offered by the local market in Cameroon also enable producers to adapt themselves and benefit from other market opportunities: (i) use of small-scale presses to cope in the event of a breakdown or saturation of oil mills during the peak period, thereby limiting the risk of production losses (figure 4), (ii) FFB sales to the non-industrial sector or oil

${ }^{9}$ Sale estimations based on the following data: 24,000 ha of selected non-estate plantations in production in 2002, with an average of $6 \mathrm{t} \mathrm{FFB/ha.} \mathrm{Indus-}$ try purchased 50,000 t of FFB. 14\% extraction rate. Oil sold for 350 CFA F/litre. processing to overcome cash-flow problems, (iii) non-industrial processing to benefit from the lucrative low-season market [10].

\section{Previous crop cover, deforestation, replanting?}

In Ivory Coast, family farms started setting up oil palm plantations at the end of a coffeecocoa cycle; the plantations therefore primarily replaced old coffee and cocoa plantings. This phenomenon contributed to the "forest rent" phenomenon driven by the cocoa economies, which led to coffee and cocoa being planted on forest land and the old plantings being replaced with other crops $[17,18]$

Léonard (1997) [19] showed that in the Sassandra area, where most of the oil palm areas were planted after 1985, the enthusiasm for oil palm

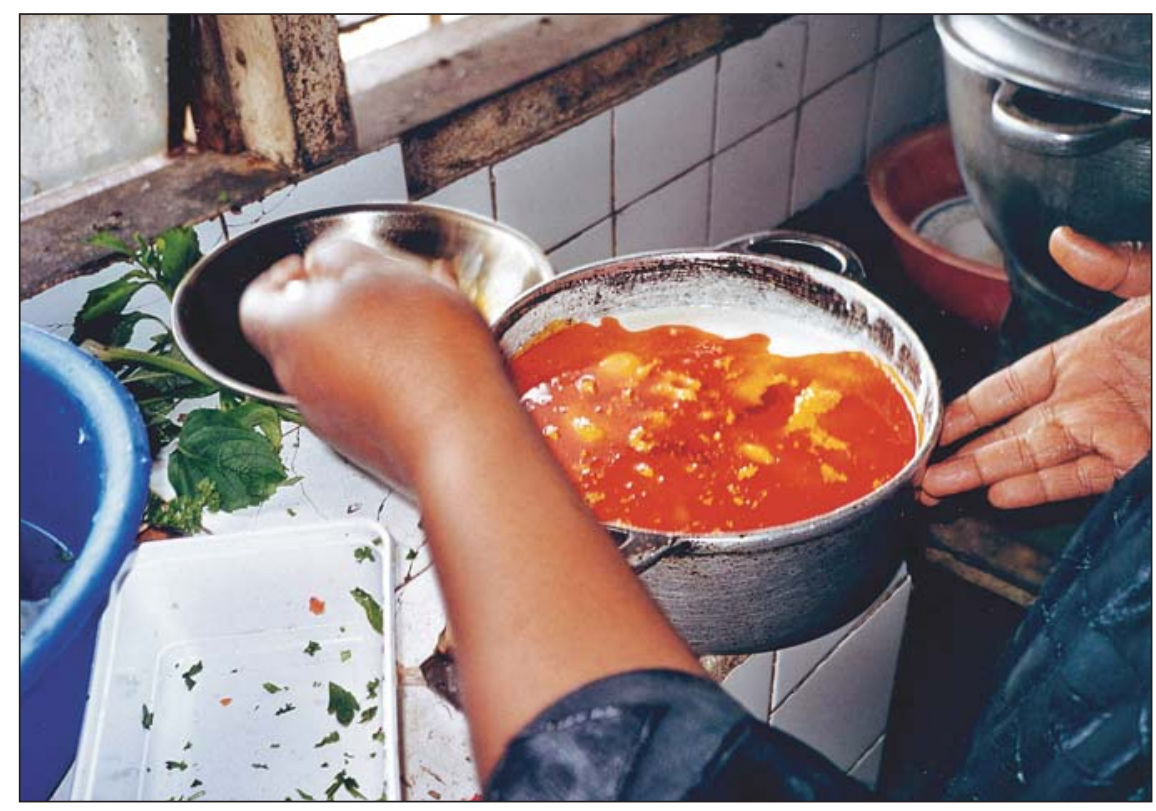

Figure 4. Cameroonian dish made with red palmoil. 
Table 3. Oil palm areas (ha) per type of grower and previous crop cover (sample of growers buying seeds at La Mé).

\begin{tabular}{|lcccccc|}
\hline & \multicolumn{5}{c}{$\begin{array}{c}\text { Land cover preceding oil palm } \\
\text { (Total areas in hectares) }\end{array}$} & $\begin{array}{c}\text { Number of } \\
\text { growers }\end{array}$ \\
\cline { 2 - 6 } & Forest & Fallow & $\begin{array}{c}\text { Old } \\
\text { cocoa }\end{array}$ & $\begin{array}{c}\text { Old } \\
\text { coffee }\end{array}$ & $\begin{array}{c}\text { Oil } \\
\text { palm }\end{array}$ & \\
\hline Retired executive & 269 & 0 & 0 & 0 & 0 & 4 \\
Middle and senior executives & 188 & 5 & 10 & 18 & 12 & 14 \\
Junior executive, teacher, etc. & 12 & 11.5 & 2 & 12.5 & 4 & 18 \\
$\begin{array}{l}\text { Family farmer, with more than 50\% of his } \\
\text { plantation given over to oil palm }\end{array}$ & 27 & 84 & 7 & 45 & 2 & 18 \\
$\begin{array}{l}\text { Family farmer with less than 50\% of his } \\
\text { plantation given over to oil palm }\end{array}$ & 5 & 35 & 4 & 4 & 12 & 23 \\
Total & 501 & 135.5 & 23 & 79.5 & 30 & \\
\hline
\end{tabular}

Source: Naï Naï et al., 2000.

growing corresponded to a diversification objective when faced with ageing coffee and cocoa plantations, and with replanting problems. In the Lagoon region, only $12 \%$ of farmer oil palm plots and $20 \%$ of rubber plots were planted on former forest land, whereas $78 \%$ of the cocoa and coffee plots were planted on former forest land [8]. In the Aboisso region, of the new crops planted after old cocoa/coffee plantings had been felled, $69 \%$ were oil palm or rubber. Only $19 \%$ of cocoa/coffee plots were replanted with cocoa or coffee (ditto). Oil palm growing does not require any additional investment when replanting on former crops or fallow. On family farms, where the area is smaller, this crop does not necessarily mean deforestation. Ivory Coast provides an example. This said, data are lacking for the other countries. For instance, in their survey among 80 growers purchasing seeds from the La Mé station, Naï Naï et al. (2000) [3] showed that among some categories of producers, family farmers and the junior executive category (usually living in the village), oil palm was used to bring fallow back into production, and for replanting/ diversification after cocoa and coffee (table 3). On the other hand, within the executive category planting large areas (middle and senior executives), oil palm remained a crop that led to deforestation. Land availability, and the ways of acquiring land for planting over large areas all in one block, led to forest zones being sought to set up new oil palm plantations. Despite the positive aspects of this vitality among the agricultural executive categories, the large areas obtained by some of them might well lead to disputes with smallholders in the coming years.

\section{Oil palm production on family farms: a diversification choice}

Development of the African oil palm commodity chain from the 1960s onwards led to economic orientations that were primarily indus- trial: dissemination of a selected hybrid variety, oil extraction in large-capacity oil mills, creation of estates and outgrowers "supervised" in the use of standardized crop management sequences geared towards maximum profitability of the oil palm plantation. Yet during that period, and especially now, since the commodity chain was liberalized, other cropping and processing systems developed. These were often described as a "deviation from the norm" (agroindustrial) and reflected a diversity of planting materials, crop management sequences and processing methods [5]. Although these technical systems are less productive, they are based on other logics.

There are two differing logics, one is industrial and international and based on profitability and standardization, the other is local, oriented towards security and heritage, and is based on diversification of resources. In Ivory Coast, the system of local outlets for oil palm products appears to be a response of producers to the uncertainty surrounding privatization. It is adapted to the dual logic of securing and stabilizing income, notably by diversifying trading possibilities.

\section{Oil palm: \\ monoculture or income diversification?}

Family farms that produce oil palm virtually all have diversified crops and activities. The surveys in Ivory Coast revealed diversified farming systems that included oil palm and/or rubber, coffee and cocoa, along with food crops including cash crops, all on the same farm [8, 7]. The results given above show that oil palm has been used in some regions to diversify from coffee and cocoa. Highly lucrative prices (up to 1999 in Ivory Coast) stoked that enthusiasm. Family farmers who grow oil palm are therefore (virtually) never producers of a single crop.

In Cameroon, oil palm farmers grow other crops, at least food crops, and in some zones other tree crops such as coffee and cocoa. Rafflegeau and Ndigui (2001) [10] showed that oil palm could be a crop of partial substitution, replacing coffee for example for which prices remain relatively unattractive, or for diversification of cash crops, such as cocoa or rubber. In a context of local FFB processing, where very little of the oil goes for export and its average annual price on the local markets remains stable (apart from fluctuations associated with seasonal production), it is a crop that reassures farmers.

Beyond such diversification, family farms also intercrop juvenile oil palms with certain other crops: oil palms may therefore be interplanted with food crops for the first 4 years after oil palm planting. For instance, in Cameroon, whether on family farms or on small to medium-sized farming enterprises, food crops are usually grown in most juvenile oil palm plots, either over the entire plot or in part of it. Only $19 \%$ of the plots visited had never been intercropped with food crops. That rate was indicative of the fact that standards recommended by technical project managers had not been respected (do not plant intercrops that limit oil palm productivity), and of true practices guided by logics internal to the farm. Food crops were grown by the farmer (60\% of cases), the spouse (59\%), a "life tenant" of the land (27\%), all the women on the farm (10\%). The most frequent food crops were: plantain (in $47 \%$ of plots with food crops), macabo cocoyam $(36 \%)$, groundnut $(32 \%)$, cassava $(30 \%)$, then maize, yam, taro and pistachio [10].

In Ivory Coast the food crop precedent, and juvenile oil palm/food crop intercropping, were also frequent practices. Food crop growing, whether carried out by people seeking land or by the farmer himself, helped in plot preparation. The area cleared was used for holing. Once planting was completed, the seedlings benefited from minimum upkeep carried out for the food crops with which they coexisted. This intercropping situation usually lasted until the shadow cast by the oil palm fronds became too dense. The intercrops involved were usually cassava, pulses or even rice [9]. Cassava intercropping in immature oil palm plots can lower oil yields ${ }^{10}$. But within such strategies, farmers do not reason in terms of the profitability of a single crop. The crops intercropped with oil palm during the first four years enable farmers to diversify their income (cassava for sale), benefit from a worthwhile labour contract (possibility for the labourer to plant food crops during the first four years subject to sharecropping), or benefit from the

\footnotetext{
${ }^{10}$ According to trials conducted when the first oil palm plan was launched by research stations in the 1960s. Apparently, the trials were subsequently abandoned.
} 
inputs provided by the intercrop (as for pineapple cultivation). These practices are concrete ways of managing or circumventing the need for labour and for financial investment by the farmer in a context of limited resources [9].

An analysis of oil palm/food crop intercropping systems near Abidjan revealed the recent appearance of a new type of oil palm plantings managed over a fifteen-year cycle, where the main product is palm wine, then secondarily the FFB. Cassava during the first 4 years after planting provides substantial income for the family.

What are the aims of such diversification? Diversification satisfies several requirements: feeding the household, coping with defective markets that have an influence, limiting the risk of income loss in the event of an internal or external shock. Farmers all produce food crops for sale and/or self consumption. The evolution of a family farm in both countries always begins with food crop production, it is a dietary necessity, but also a way of gradually procuring the capital required to set up a plantation. Indeed, access to capital or credit is a prime requisite for planting. Diversification and intercropping enable local arrangements to be made that partly solve this limited access (such as food intercropping in the interrows, which helps to reduce upkeep costs in the juvenile phase). Lastly, diversification makes it possible to limit the risk of income loss, particularly when there is dependency on pricing factors that are fixed on other markets, as is the case for FFB prices in Ivory Coast, but also for cocoa and coffee, other liberalized sectors. It makes it possible to spread income over the year (with cocoa bringing in an annual income, whilst oil palm makes it possible to maintain a virtually monthly or even daily income). Insurance, like credit, is inaccessible and diversification makes it possible to manage the risk of field losses that would be irreversible for a farming household.

These production conditions lead to a rationality that is not geared towards the maximum profitability (or productivity optimum) of the "oil palm crop" on family farms, unlike the management of a one-crop farming enterprise in an estate. Diversifying and intercropping crops in a restricted land area with limited resources leads to crop management sequences that are necessarily less productive than a single intensive crop. The rationality is more geared towards the profitability of the farm as a whole and towards its insertion within a system of social organization, towards perpetuation (risk management) initially, then towards its development.

\section{Diversity}

of technical management systems

This diversification partly explains a different way of managing oil palm growing from that found on estates.

\section{Choice of planting material}

In both Cameroon and Ivory Coast, the areas planted with unselected oil palms are not known on a national level.

In Ivory Coast, zones near the large urban centre of Abidjan are renowned for substantial use of cheaper, lower-yielding "unselected" planting material. The survey conducted in the Lagoon region, near Abidjan, brought out certain traits of that use. In this region, the study confirmed the high rate of "unselected" seed adoption, since $75 \%$ of growers had at least one oil palm plot planted with that type of material. In terms of the total areas planted, including areas already felled, $40 \%$ of the areas had been planted with "unselected" material. $43 \%$ of growers bought that planting material from travelling salesmen or informal networks [7].

This practice began in the region during the second oil palm plan (1985-1990), as the supply of selected plants fell short of demand, but this tendency continued even after access was opened up to selected planting material.

If selected oil palm growing is to achieve good yields, it requires initial investment in inputs (fertilizers and selected seeds) during the first four years, estimated at between 300,000 and 400,000 CFA F $^{11} /$ ha in Ivory Coast. These high costs are a major handicap compared with the low costs of the oil palm/food crop system, notably when it is primarily intended to produce cassava, then palm wine.

Farmers who possess capital do not necessarily invest it in oil palm, but in other activities such as natural rubber growing (purchase of budgrafted plants), food crops, and in tools to process those products (cassava processing equipment), or in real estate or a business. Such strategies are sometimes presented as forms of risk reduction, in what is currently a very uncertain context in terms of FFB prices (sharp drop in prices since 1999) but also in terms of commodity chain organization (bunch collection difficulties during the 2001 season that rendered sales insecure).

These strategies for limiting risks by investing in other activities, combined with less intensive oil palm cultivation, reflect the other opportunities available to growers in this region for selling their FFB. In addition to selling their production to an oil mill, they can sell FFB and /or oil via the non-industrial sector at worthwhile

\footnotetext{
$\overline{11} 1$ Euro $=656$ CFA F.
}

prices. Most growers sell some of their FFB to small-scale women processors, and those sales amount to a quarter of the income they derive from sales to an oil mill. They may also use FFB for their own consumption (85\% of households make oil themselves for their consumption). Felling oil palms provides a not insubstantial capital for palm wine extraction (400,000 CFA F per hectare). There is a guaranteed return on investment. We shall see that in Cameroon, selling oil palm stands for palm wine extraction is used to get young farmers who do not have any capital off to a start.

\section{Technical management}

The survey conducted in Ivory Coast at Dabou, Divo, Soubré and Aboisso indicated a tendency towards less intensification since privatization of the commodity chain [9]. The practices found stood out from the recommended crop management sequences: use of fallow and bottomlands, notably in zones marked by land use saturation; substitution of chemical fertilizers with compost made by farmers, substitution of wire guards to protect seedlings with strips of bamboo, reduction or increase in the space between palms, fragmentation of plots with staggered planting. These practices were associated with the already mentioned practices of immature palm intercropping with food crops, and crop diversification on the same farm.

In Cameroon, the same diversity of crop management sequences was found (Annex 1). Concerning the particular case of fertilizers, $53 \%$ of growers in the sample did not use or no longer used fertilizers (33\% of the areas). Only $38 \%$ of growers applied them regularly (every year). Regular fertilizer application concerned "farmers", salaried workers, and growers from the "elite", in equal proportions. It should be noted that it was not linked to a type of grower, but rather to a critical plantation size. It was more frequent for plantations of more than 50 ha, but also for those between 5 and 10 ha (table 4). When farmers or investors reached their target oil palm hectarage, they sought to intensify their yields by applying fertilizers as they were no longer in a phase of investing to set up their plantation and could therefore devote resources to fertilization.

Very limited access to capital lead to minimum investment strategies when setting up a new oil palm plantation, and to a staggering of set-up costs: managing one's own nursery, planting on fallow (avoiding the cost of forest clearance), first growing food crops for 1 or 2 years before planting oil palm, so as to stagger the costs of setting up the oil palm plantation, producing food crops intercropped with the oil palm seedlings to fund plot upkeep, purchasing cheap seedlings. 


\begin{tabular}{|c|c|}
\hline \multicolumn{2}{|c|}{$\begin{array}{l}\text { Annex 1. Smallholder oil palm growing during different phases } \\
\text { of the FONADER project then after its closure and the privatization } \\
\text { of public development companies in Cameroon }\end{array}$} \\
\hline FONADER project / State agroindustries & Outside project / Privatized agroindustries \\
\hline \multirow{3}{*}{$\begin{array}{l}\text { Setting up: } \\
\text { 1. Credit only granted for plots prepared in time and } \\
\text { only on former forest land (beginning of project), in } \\
\text { a radius close to the oil mills participating in the } \\
\text { project } \\
\text { 2. PM: supplied in the form of selected plantable } \\
\text { seedlings that were well developed at the right time }\end{array}$} & Setting up: \\
\hline & $\begin{array}{l}\text { 1. No credit, setting-up financed from private funds } \\
\text { requiring a minimum savings ability (farmers pay } \\
\text { out an average of } 200000 \text { CFA F/ha to plant } \\
\text { selected PM) }\end{array}$ \\
\hline & $\begin{array}{l}\text { 2. Any previous plant cover used throughout } \\
\text { southern Cameroon }\end{array}$ \\
\hline \multirow[t]{4}{*}{$\begin{array}{l}\text { 3. Advice and help with lining / Al supervisor } \\
\text { 4. Wire guards for rodent protection supplied on } \\
\text { credit }\end{array}$} & $\begin{array}{l}\text { 3. PM: Sale by Als of selected plantable plants that } \\
\text { were well developed at the right time, sale of mostly } \\
\text { unselected plants by private nurserymen, sale of } \\
\text { germinated seeds by La Dibamba and Pamol, sale of } \\
\text { open pollinated germinated seeds by staff and } \\
\text { neighbours of La Dibamba and Pamol. }\end{array}$ \\
\hline & 4. No advice and no supervision of farmers' nurseries \\
\hline & 5. Advice and help with lining / State official \\
\hline & $\begin{array}{l}\text { 6. Protection from rodents with wire guards, } \\
\text { bamboo, sheet metal, half drums, tyres, or no } \\
\text { protection }\end{array}$ \\
\hline \multirow{7}{*}{$\begin{array}{l}\text { Management in the juvenile phase: } \\
\text { 1. Fertilizers supplied on credit, and advice given on } \\
\text { how to apply them } \\
\text { 2. Credit for soil upkeep (beginning of project) } \\
\text { 3. Food crop intercropping banned (beginning of } \\
\text { project) }\end{array}$} & Management in the juvenile phase: \\
\hline & $\begin{array}{l}\text { 1. Fertilizers supplied on credit, and advice given on } \\
\text { how to apply them for those supplying to an Al and }\end{array}$ \\
\hline & wishing to fertilize, high transport costs, and \\
\hline & $\begin{array}{l}\text { untamiliarity with the fertilizers and application rates } \\
\text { for the others }\end{array}$ \\
\hline & $\begin{array}{l}\text { 2. Food crop production very frequent, to help in } \\
\text { soil upkeep. Upkeep often insufficient without food }\end{array}$ \\
\hline & $\begin{array}{l}\text { crops, or after harvesting, leading to seedling losses } \\
\text { due to rodents. }\end{array}$ \\
\hline & 3. No technical support \\
\hline \multirow{5}{*}{$\begin{array}{l}\text { Management in mature phase: } \\
\text { 1. Fertilizers supplied on credit, and advice given on } \\
\text { how to apply them } \\
\text { 2. Technical support to growers in preparation for } \\
\text { full production (circle weeding, interrow and crown } \\
\text { upkeep) } \\
\text { 3. Harvesting organized and supervised by a team of } \\
\text { supervisors for project farmers }\end{array}$} & Management in the mature phase: \\
\hline & $\begin{array}{l}\text { 1. Fertilizers supplied on credit, and advice given on } \\
\text { how to apply them for those delivering to an } \mathrm{Al} \text { and }\end{array}$ \\
\hline & $\begin{array}{l}\text { who wished to fertilize, high transport costs and } \\
\text { unfamiliarity with the fertilizers and application rates } \\
\text { for the others }\end{array}$ \\
\hline & 2. No technical support \\
\hline & $\begin{array}{l}\text { 3. Harvesting organized and supervised for those } \\
\text { farmers delivering to an oil mill }\end{array}$ \\
\hline \multirow{5}{*}{$\begin{array}{l}\text { Outlets: } \\
\text { 1. FFB sales directly at the mill } \\
\text { 2. Farm-gate collection by oil mills for farmers } \\
\text { benfiting from the project } \\
\text { 3. Appearance and development of processing. }\end{array}$} & Outlets: \\
\hline & 1. FFB sales directly at the mill \\
\hline & $\begin{array}{l}\text { 2. Farm-gate collection by oil mills over various } \\
\text { distances depending on the distance-production }\end{array}$ \\
\hline & combination of the zone considered \\
\hline & $\begin{array}{l}\text { 3. Small-scale processing: necessary when far from } \\
\text { oil mills, and for those with unselected oil palms } \\
\text { (many dura bunches downgraded by the oil mills), } \\
\text { more worthwhile for some, more flexible for gaining } \\
\text { funds when market prices are high, when collection } \\
\text { is halted (track not passable, insufficient yields to fill } \\
\text { a truck) }\end{array}$ \\
\hline
\end{tabular}

The variability of situations between different agroindustrial companies is limited, whereas it is considerable from one family farmer to the next due to structural differences between farms, to the aims of the farmers and to their know-how. At least 3 types of variables can to inputs, to technical advice, to information, and especially to credit) and (iii) the structure of the farm and of the family: labour, area farmed and available within the household, available income, etc.

Variation in cultural practices (type of seeds, inputs, etc.) has an effect on FFB and oil yields ${ }^{12}$. The diversity in social and technical forms of oil palm production have to be associated with an investment diversification logic, but also with a logic of adapting supply to the multiple types of local use for oil palm resources, combined with the proximity of a captive market for non-industrial palm oils and palm alcohols [7].

For family farms, the problems arise in terms of access to capital or credit, connections with agricultural advice, access to information and inputs, and negotiating abilities.

\section{Minimum agricultural conditions}

\section{Minimum area}

Development plans include the creation of smallholdings, for which the number of hectares is fixed in a standard manner. However, if enough income is to be generated to enable producers to accumulate, invest and school their children, thought has to be given, among other things, to a minimum production area. Few studies have been carried out on this subject in Africa. In Indonesia, a study based on a survey of 1172 producers in 4 provinces [20], in a context of given prices, established area thresholds required to reach different levels: level of survival, level of production, level of plantation reproduction and level of socioeconomic reproduction ${ }^{13}$.

Taking a standard household of 5 members with a work force equivalent to 2 adults, and

\footnotetext{
${ }^{12}$ In Ivory Coast, average yields in 2000 were 10.5 $\mathrm{t} / \mathrm{ha}$ on estates and $7.6 \mathrm{t}$.ha on smallholdings [11]. In Cameroon in 2002, 7.8 t/ha on estates and $6 \mathrm{t} / \mathrm{ha}$ on smallholdings [10].

${ }^{13}$ Household survival: enables the household to cover its basic requirements for survival only. Below this level, households tend to disappear as agricultural producers, pulling out of agricultural activity (selling or renting out their land), and/or selling their labour. Production: makes it possible to constitute a work force and procures the inputs necessary for maintaining a productive plantation. Plantation reproduction: this is the production level, plus replanting or renewal costs. Socio-economic reproduction: in addition to the previous level, this includes the cost of schooling 3 children up to the end of secondary school, making it possible for some children to have work other than in agricultural production and avoid the division of the farm into non-viable plots as they become too small [20].
} 
Table 4. Frequency of fertilizer application on oil palms, depending on the "type" of farmer and the total oil palm area per farmer (Cameroon).

\begin{tabular}{|lcccc|}
\hline & Never & "FONADER" & Irregular & Annual \\
\hline Farmers & $22 \%$ & $22 \%$ & $17 \%$ & $39 \%$ \\
Occasional farmers & $37 \%$ & $26 \%$ & $11 \%$ & $26 \%$ \\
Town dwellers, civil servants, employees & $19 \%$ & $28 \%$ & $6 \%$ & $47 \%$ \\
The "elite" & $55 \%$ & $0 \%$ & $0 \%$ & $45 \%$ \\
\hline Total number & $30 \%$ & $23 \%$ & $9 \%$ & $38 \%$ \\
\hline Under 5 ha & $37 \%$ & $29 \%$ & $13 \%$ & $21 \%$ \\
From 5 to 10 ha & $13 \%$ & $25 \%$ & $8 \%$ & $54 \%$ \\
From 10 to 50 ha & $39 \%$ & $21 \%$ & $7 \%$ & $32 \%$ \\
Over 50 ha & $20 \%$ & $0 \%$ & $0 \%$ & $80 \%$ \\
\hline
\end{tabular}

Source: Rafflegeau and Ndigui, 2001 [10].

a "FONADER": These farmers applied fertilizers while FONADER credit existed, then stopped.

only taking into account the oil palm areas, this study showed that it takes 3.6 ha to pass the limit of socio-economic reproduction and enter an accumulation/development phase; it takes more than 2.3 ha to pass the limit of plantation reproduction and it takes at least 2 ha to pass the limit of survival and enter a "production" phase, i.e. ensure not only the survival of the household but also that of the productive activity (even without accumulation). To envisage accumulation and the schooling of children, and the viability of the farms (no division) all at the same time, it would therefore take more than 3.6 ha per farmer. The calculations can be done considering a combination of crops on the farm. The merit of this approach is to define this minimum area for development plans that envisage setting up outgrower plantations in return for the installation of industrial projects on new land, with input supplies for the set-up phase. It is then essential to consider what will enable outgrowers to progress beyond the socio-economic reproduction limit, to ensure sustainability and efficiency, and alleviate rural impoverishment.

The first estimations can be put forward for Cameroon, but they need to be confirmed. Farmers who have small oil palm areas or who are starting up (investment phase, creation of an oil palm plantation) need to compensate by growing some food crops. 2 ha of bearing oil palms would seem to be a minimum level for a couple (and notably the case of a retired couple); these 2 ha do not make it possible to fund an extension. In all situations, 2 ha in production would be insufficient to live off the proceeds from the oil palm plantation and at the same time extend the areas planted, irrespective of the family situation. Under the FONADER project, those who benefited from credit for 2 ha in the first phase rarely extended their oil palm planting using their own resources. Around ten years later, they benefited from credit again, and it is when that new plot started bearing that they were able to fund and then extend their plantations with income from their activity. 5 ha in production for a family with children at school would appear to be a minimum limit. 10 ha in production, even if some is planted with "unselected" material, would be the adequate capacity that would be sought by farmers, and this also presupposes employing a full-time labourer for pruning and bunch harvesting. A 10 ha target for oil palm is frequent. Farmers who have been able to benefit from aid or who had considerable ease in starting up (e.g. due to a salaried activity) aim more at 15 to 20 ha.

\section{Access to credit}

Oil palm growing requires fairly substantial capital when setting up plantings that will only provide an initial income 4 years later. Research in Cameroon has been backed up with a system for simulating the different practical situations of family farmers [21].

Simulation of the case of a farmer setting up 3 ha of selected oil palms, in 3 phases, following the recommended crop management sequences, indicated how long it would take to procure a return on investment. The farmer invested 300,000 CFA F in two goes to set up the first 2 ha in years 2 and 5 . In year 8 , the third hectare could be virtually self-financed with income from the previous two plots which had started bearing. Assuming that all the income from the first plots was used for the extension of the 3rd hectare, the farmer therefore had to work for 8 years in a plot and invest substantial capital on 2 occasions, before he could start earning a profit from his investment. Fifteen years after the first plot was set up, the total 3 ha provided a monthly income of 100,000 CFA F. But this assumes that it is possible to work for 8 years in the oil palm plantation without any return, invest substantial sums on two occasions, and otherwise meet the needs of the household.

When such initial investment is not possible, farmers adopt other strategies. It is possible to reduce the investment devoted to setting up and managing the plantation by following a more extensive crop management sequence, without fertilizer applications and with upkeep rounds spaced further apart.

Fifteen years ago, planting "unselected" material was still a strategy for getting young farmers without capital off to a start, a transitional stage towards a selected oil palm plantation, which remained the ultimate aim. Thus, the least well-off farmers, even though they were well aware of the difference between unselected and selected oil palms, planted unselected material to set up an oil palm plantation with very little financial investment. The plantation generated income (FFB sales) and standing capital (sale of oil palms for palm wine), enabling them to replant gradually or extend their plantations with selected plants. Simulations indicated the income, expenditure and positive balance for a farmer who planted 3 ha of unselected oil palms over 3 years, then began to replant with selected planting material in an extensive way when the first plot had reached 10 years old, staggering his replanting over 3 years. This strategy partly arises from an originality of oil palm plantations in Africa, whereby a felled plantation makes it possible to gain capital ${ }^{14}$. With agroindustries reducing the price they paid for dura FFB from "unselected" oil palm plantings in 2002, this type of approach is no longer feasible for a farmer delivering to an oil mill.

These strategies are particularly decisive in contexts where access to bank credit is virtually nonexistent for smallholders. The survey by Nai Naï et al. (2000) [3] among growers who bought their planting material from the La Mé station in Ivory Coast (the only sale point at the time of the survey) provided a description of their profile. These growers were not representative of the overall population of growers: $62 \%$ of the growers buying selected seeds in La Mé had an education up to secondary school level or beyond, $38 \%$ were in salaried work, and $52 \%$ were not resident at the production sites!

This study also revealed particularities in the way different types of growers resorted to capital (table 5). Among the family farmers "with less than $50 \%$ of their farm planted with oil palm", the main sources of funding for the new oil palm plot were earnings from cocoa and coffee, or from other crops, along with an addition provided by family assistance. This shows the diversification process undertaken by coffee and cocoa growers on the one hand,

\footnotetext{
${ }^{14}$ In Ivory Coast, farming one hectare of oil palms felled for palm wine extraction earns the farmer between 350,000 CFA F and 420,000 CFA F (2001 data). That money would serve to fund replanting or other investments (housing, business, etc.) and/or cover domestic expenditure.
} 
Table 5. Oil palm area (ha) before the survey and source of capital depending on farm type (sample of growers buying selected planting material at La Mé).

\begin{tabular}{|c|c|c|c|c|c|c|c|}
\hline & \multirow{2}{*}{$\begin{array}{l}\text { Number in } \\
\text { category }\end{array}$} & \multirow{2}{*}{$\begin{array}{l}\text { Total } \\
\text { area }\end{array}$} & \multirow{2}{*}{$\begin{array}{l}\text { Average area } \\
\text { per farm }\end{array}$} & \multicolumn{4}{|c|}{ Source of capital for oil palm planting (number of growers) } \\
\hline & & & & $\begin{array}{l}\text { Oil palm } \\
\text { income }\end{array}$ & $\begin{array}{l}\text { Income from cocoa, } \\
\text { coffee and other crops }\end{array}$ & Salary & $\begin{array}{c}\text { Family } \\
\text { assistance }\end{array}$ \\
\hline Retired executive & 4 & 269 & 67.2 & 4 & 0 & 0 & 0 \\
\hline Middle and senior executive & 14 & 380 & 29.3 & 2 & 0 & 9 & 0 \\
\hline Junior executive, teacher, etc. & 18 & 57 & 3.3 & 0 & 1 & 14 & 0 \\
\hline $\begin{array}{l}\text { Family farmer, with more than } 50 \% \text { of his farm } \\
\text { given over to oil palm }\end{array}$ & 18 & 189 & 10.2 & 12 & 2 & 0 & 1 \\
\hline $\begin{array}{l}\text { Family farmer with less than } 50 \% \text { of his farm } \\
\text { given over to oil palm }\end{array}$ & 23 & 63 & 2.8 & 4 & 11 & 0 & 3 \\
\hline Total & & & & 22 & 14 & 23 & 4 \\
\hline
\end{tabular}

Source: Naï Naï et al., 2000 [3].

but also that the first oil palm plots are not large enough to cover the cost of funding extensions.

Among retired farmers and family farmers with a majority of oil palms, accumulation from this crop then becomes sufficient to fund investments to extend the oil palm plantation. Lastly, among executives still in employment, it is the salary that is the main source of funding. This confirms the paramount nature of access to capital and to outside income in adopting a new perennial crop such as selected oil palms, due to the cost of investing in planting material.

Consequently, only certain categories of producers have access to selected planting material in a context where there is little possibility of obtaining credit.

\section{Access to information}

The above results state that using "unselected" planting material or extensive crop management sequences does not necessarily arise from a misunderstanding, it may be part of a strategy. In particular, the study conducted in the Lagoon region showed that adoption of unselected material was not linked to a lack of information [7].

This said, in some remote regions there still exist some practices that are due to an unawareness of profitability factors or of places that guarantee the origin of seeds. Consequently, when a farmer has not been able to go to the only official sale point, fraudulent claims about seed origin are still very frequent. This raises the question of selected planting material distribution in the medium term: how can access to selected planting material be facilitated in remote regions, whilst guaranteeing quality?

Access to information also depends on having a grasp of that information, which helps to improve the negotiating ability of producers.

\section{Negotiating abilities and access to negotiating arenas}

In terms of commodity chain organization, with privatization and State withdrawal it might have been feared that an "institutional vacuum" would be left, notably for access to credit, arbitration of disputes, and organization of the sector. In Ivory Coast, producer cooperatives, then the joint-trade association, became links in the chain that were supposed to fill the gap. A strong policy of promoting cooperatives had a direct effect. In 2003, twelve oil palm grower cooperatives were approved by the Ministry of Agriculture, in compliance with the new law on cooperatives. They were organized along lines intended to provide an incentive: one cooperative per nucleus estate, the establishment of an elected board of directors, but also a professional salaried team, etc. These criteria enabled producers to acquire substantial and effective negotiating power, obtaining an increase in the FFB purchasing price, then a revision of the pricing mechanism as a whole (2002), and lastly, in some cases, the transfer of certain activities such as bunch collection (2003) to their responsibility. The emergence of a power of representation for farmers within the sector's organization led to the State resuming its arbitration role, the establishment of multipartite consulting bodies in 2002, the creation of a Federation of Oil palm Farmer Cooperatives in 2003, and finally a Joint-Trade Association.

\section{Conclusion}

The socio-economic dimension of a family farm has long been obvious for maintaining rural populations in place. The results described here show that these farmers are also technical players who adapt their practices to their constraints and opportunities.

Policies cannot be limited to solutions designed to improve yields and productivity, which are necessary for keeping in step with increasing food demand, but which are inadequate for dealing with the central issues of employment and sustainability [22].

The tensions seen between operators in the oil palm commodity chain since the 1960s, specially visible in Ivory Coast since liberalisation, are a result of two different logics: one industrial and international, based on profitability and standardization, the other more local and security minded, based on heritage creation and optimum use of resources, income diversification and risk limitation strategies.

It is not possible to foresee the behaviour of farmers by considering them as a uniform group; they are stakeholders in a commodity chain that is evolving and they adapt themselves according to changes in their own situation and in the commodity chain environment within their production zone.

It is even more perilous to consider that family plantations, along with estates, belong in the same normative group, as we have seen that their logics and realities differ. In negotiations on sustainable palm oil criteria, this state of affairs ought to lead to a prior analysis of family agricultural practices, considering their technical, environmental and social angles. It is not sure that smallholder and estate areas raise the same environmental problems. Neither is it sure that the standards that will be adopted by estates to reduce their pressure on the environment and maintain a certain degree of biodiversity will correspond to reality in the management of family farms. Past experience has shown that standards applicable to strict estate monocultures do not "fit into" a family farm logic. If these realities were taken into account, it would be possible to avoid the stalemates arising from attempts to "bring family farms up to standard". On the other hand, by starting from the current and real organization of these farms, some headway could be made on a major question: how will oil palm growing contribute to sustainable development? Bosc 
and Losch (2002) [22] underlined, in Africa, the appearance of several types of agriculture: farming enterprises benefiting from direct investments, a growing fringe of marginalized farms undergoing accelerated impoverishment, an intermediate mass of family farms that may rapidly fall into the previous category. They propose a discussion on what model are "sustainable"?

Although some producer organizations, as in Ivory Coast, have acquired a nationwide negotiating ability, they must now also target the international arenas, and be able in these new forums to take part in the debate on agriculture and trade policies. They alone can ensure direct representation of family farmer interests. Agricultural research on the oil palm, which was traditionally geared towards improving yields and techniques on estates, has very recently made an effort to take an interest in family farming systems. If this trend persists, it could lead to novel research results that incorporate family agriculture logics, such as intercropping, agroforestry systems, etc., that are connected to local markets (variety improvement geared towards local food demand). Lastly, trading on the local market, which is possible in Africa, is a clear opportunity for producers [23], in a context where prices on the international market are declining and where producers have relatively little influence in the market structures that prevail in the international segments (oligopolistic structures where considerable inequalities persist in the balance of power between the upstream and downstream sectors of the commodity chains). In that sense, the growth in African towns is an opportunity for family agriculture. The WALTPS study (West African Long Term Perspective Study), conducted by the Sahel Club, showed that the urban population of West Africa rose from $4 \%$ of the population in the mid-1930s to $40 \%$ in the mid-1990s, and that this region should have around thirty towns with over a million inhabitants by 2020 (as opposed to six in 1990) ([24], cité par Daviron).

These towns also offer job opportunities [23], but they are limited and the region cannot afford to let its agriculture disappear. In Africa, the active agricultural population still amounts to $66 \%$ of the total active population, and the agricultural population increased in $56 \%$ over the 1975-2000 period [22].

\section{REFERENCES}

1. JANNOT C. Oil palm in Africa. BUROTROP 2003; 19: 15-8
2. HIRSCH RD. La filière huile de palme au Cameroun dans une perspective de relance. Agence Française de Développement, 1999; (45 pages).

3. NAÏ NAÏ S, CHEYNS E, RUF F. L'adoption du palmier en Côte d'Ivoire. OCL 2000; 7(2): 155 65

4. CHEYNS E, AKINDES F, AKA ADIE F. La filière palmier à huile en Côte d'Ivoire trois ans après la privatisation: Etat des lieux d'un procès de recomposition institutionnelle. OCL 2000; 7(2): 166-71.

5. CHEYNSE, AKINDES F, KOUAMÉ YS. Le palmier à huile en Côte d'Ivoire: deux logiques pour une filière entre normalisation et diversité des produits. In: Charlery de la Masselière $B$, ed. Fruits des terroirs, fruits défendus. Identités, mémoires, territoires. Toulouse, France: Presses Universitaires du Mirail, 2004: 197-213.

6. SAN CORTÉS R. Terminology used in "family agriculture systems" research. CIRAD-TERA $n^{\circ} 49 /, 2003 ;(20$ p).

7. CHEYNS E, KOUAME YS, NAÏ NAÏ S. Itinéraires techniques et nature du matériel végétal: diversité des formes sociales et techniques de production en Côte-d'Ivoire. OCL 2001; 8(5): 524-8.

8. SAYAM VT, CHEYNS E. Diversification des cultures cacaoyères en Côte $d^{\prime}$ Ivoire vers le palmier à huile. Smallholders Seminar Diversifying tree crops in Africa. A show case of private sector initiatives, Kpalimé, Togo, 8-11 December. 2003.

9. KOUAME S, AKINDES F. Les ajustements dans l'économie de plantation villageoise de palmier à huile face à la privatisation de la filière en Côte d'Ivoire. In: International Conference on the Future of Perennial Crops. Yamoussoukro, 5-9 November. BNEDT-CIRAD-ESI-VU, 2001.

10. RAFFLEGEAU S, NDIGUI B. Synthèse d'enquêtes agro-économiques réalisées dans une centaine d'exploitations élaeicoles du sud du Cameroun, IRAD - Station de La Dibamba: 70 et 20 pages. 2001.

11. MINADER-COOPERATIVE. Bilan diagnostic postprivatisation de la filière palmier à huile, National Workshop"Oil palm commodity chain: organization and prospects", 17-19 September. 2002; (Ad hoc committee report 1, 75 p).

12. DURAND-GASSELIN T, KOUAME KOUAME R, COCHARD B, ADON B, AMBLARD P. Diffusion variétale du palmier à huile. OCL 2000; 7(2): 207-14.
13. CHEYNS E, BRICAS N, AÏKE A. Attentes de qualité et structuration des filières alimentaires. La segmentation du marché urbain des huiles de palme rouges en Côte d'Ivoire. Cahiers Agricultures 2004; 13(1): 135-41.

14. LAMINE C. L'huile de palme rouge à Yaoundé et Douala: usages culinaires, perception de la qualité et modes de coordination entre consommateurs et vendeurs. Rapport d'Etude. CIRAD-CP, 2003.

15. DIENG A. Quelles huiles de palme pour quels marchés au Ghana? Cas des villes d'Accra et de Kumasi. Thèse de Mastère «Développement Agricole Tropical », CNEARC, CIRAD, 2004.

16. BAKOUME C, JANNOT C, RAFFLEGEAU S, NDIGUI B, WEISE S. Revue du secteur rural: Etudes complémentaires sur le relance des filières hévéa et palmier à huile. Rapport Palmier. IRAD / CIRAD / IITA, 2002; (80 pages).

17. RUFF. Éléments pour une théorie sur I'agriculture des régions tropicales humides. IDe la forêt, rente différentielle au cacaoyer, capital travail. L'Agronomie Tropicale 1987; 42(3): 218-32.

18. RUF F. Booms et crises du cacao. Les vertiges de I'or brun. Paris: Karthala, 1995; (459 p).

19. LEONARDE. La reproduction de la société agraire dans la région de Sassandra. Intensification ou décapitalisation? In: Guillaume A, Ibo J, N'Guessan K, eds. Croissance démographique, développement agricole et environnement à Sassandra (Sud-ouest de la Côte d'Ivoire). ORSTOM, ENSEA, GIDIS, 1997: 137-60.

20. BOURGEOIS R, et al. Studies on smallholder tree crops production and poverty alleviation. Synthesis. Economy Report. Indonesian Center for Estate Crops Research and Development and World Bank, 2002; (20 p).

21. RAFFLEGEAU S. Comparaison de stratégies de création de palmeraies non industrielles au Cameroun. In: O. Deheuvels, E. Penot, Du système de culture à la petite région: modélisation du fonctionnement de l'exploitation agricole, simulation et aide à la décision avec le logiciel Olympe. CIRAD. (Due out. P. 23-43. To appear).

22. BOSC PM, LOSCH B. Situations et tendances. Les agricultures familiales africaines face à la mondialisation: le défi d'une autre transition. OCL 2002; 9(6): 402-8.

23. DAVIRON B. L'épopée incertaine des paysans africains: une approche d'histoire longue. In: Séance de l'Académie d'Agricutlure en I'honneur de Louis Malassis et de son dernier ouvrage "L'épopée inachevée des paysans du monde". 2005; (16 p).

24. COUR J.M. 